COMMENT

DOI: $10.1057 /$ s41599-018-0150-4

\title{
Understanding how China is championing climate change mitigation
}

\author{
Anita Engels ${ }^{1}$
}

\begin{abstract}
This comment deals with the question of how current political regimes could effectively contribute to the mitigation of climate change-and why this might happen. Against the backdrop of the US government's announcement to withdraw from the Paris agreement, the rise of populist governments across the globe, and the slow progress of energy transformation projects in pluralistic countries, this paper focuses on China's potential role in climate change mitigation. Since 2008, the Chinese government has switched to a proactive stance on climate governance and low-carbon development. Due to significant improvements in $\mathrm{CO}_{2}$ efficiency and a clear slow-down in the rise of its annual total $\mathrm{CO}_{2}$ emissions, China is increasingly perceived as a new low-carbon champion and appears to be in a position to take over global climate mitigation leadership. This comment examines the drivers behind current low-carbon developments in China and tests the assumption that China's state-led nonparticipatory authoritarianism will effectively offer a solution to the global climate problem. Any switch to low-carbon development rests on complex societal preconditions and requirements. This paper discusses the reasons why the likelihood that the Chinese authoritarian regime will be effective over the long-term in lowering greenhouse gas emissions is uncertain at best-because of internal contestations, low public and private-business participation, and countervailing strategies to secure China's global market positions. Understanding the foundations and nature of China's climate change mitigation championship has important implications for fostering low-carbon developments in all political regimes.
\end{abstract}

\footnotetext{
${ }^{1}$ Centre for Globalisation and Governance, Universität Hamburg, Hamburg, Germany. Correspondence and requests for materials should be addressed to A.E. (email: anita.engels@uni-hamburg.de)
} 


\section{China's new role as a global climate change mitigation champion}

W

hile the world witnessed the first global increase in carbon emissions in 2017 after 3 years without growth (Le Quéré et al., 2018), it is worth examining popular assumptions relating to the new climate change mitigation championship and leadership role of China, which became the world's single largest carbon-emitting country in approximately 2007.

The global climate governance regime has changed in several important ways in recent years. This includes a change in the architecture of the climate agreement from top down to bottom up, and a proliferation of actors, forms, and levels of governance (Aykut, 2016), leading to hybrid multi-lateralism with as yet uncertain outcomes (Kuyper et al., 2018). The announcement of the US government's withdrawal from the Paris Agreement was seen as a first major backlash. Across the world, populist parties that reject the Paris Agreement are gaining influence, and countries trying to pursue a transformation of their energy systems towards renewables are experiencing serious slow-downs. Against this backdrop China has adopted relative and absolute reduction goals and has announced a peak in its $\mathrm{CO}_{2}$ emissions by 2030 (People's Republic of China, 2015).

Observers have argued that China has introduced vigorous policies that have already effectively reduced its carbon emissions, with some commentators extending this to the expectation that China will be the new leader in global climate mitigation (Biesecker and Watt, 2017; Zhao, 2017). In terms of $\mathrm{CO}_{2}$ output, China has already shown impressive results, even though the data on which this assessment is based suffers from a certain lack of accuracy and accountability (Korsbakken et al., 2016). China's economy was heavily dependent on fossil fuels for decades, especially domestic coal, and saw a rapid growth of energy use and related $\mathrm{CO}_{2}$ emissions until 2010 (see Fig. 1). However, starting in 2008, the Chinese government adopted a proactive stance towards climate policy. Following the introduction of the 12th Five-Year-Plan (2011-2015), a policy shift towards a new low-carbon development model was introduced ( $\mathrm{Li}$ and Wang, 2012). China's rapid success in limiting its own domestic $\mathrm{CO}_{2}$ emissions has surprised many observers in the past few years,

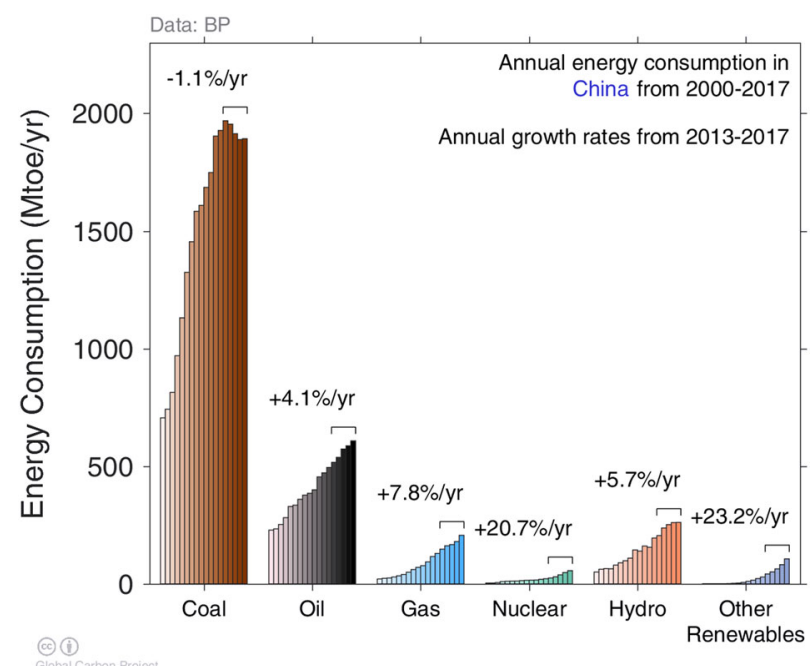

Fig. 1 Annual energy consumption by energy source in China from 2000-2017. Source: Global Carbon Project using energy data from BP. This figure is covered by the Creative Commons Attribution 4.0 International License stemming from an increase in renewable energy and a decrease in the production and consumption of coal (see Fig. 1). The rise in renewable energies implies a rapid increase in installed domestic capacity, which began under the clean development mechanism (CDM) of the Kyoto Protocol, after which China became the largest CDM recipient (Wang, 2010). As a consequence of continued massive Chinese investment in renewables, China emerged as one of the leading producers of wind and solar power technologies, and in certain segments of solar, wind, and hydro energy, it has also become an innovator and provider of South-South and South-North technology transfer (Urban, 2018).

The decrease in coal included a reduction in coal capacity, an overall decrease in the energy intensity of industrial production and fostering of cleaner coal technologies (Zhang et al., 2017; Wang/Engels/Wang, 2018). As a result, the climate action tracker (CAT) concluded from its review of the so-called nationally determined contributions (NDCs) in November 2017 that "China's $\mathrm{CO}_{2}$ emissions appear to have peaked more than a decade ahead of its Paris Agreement NDC commitment to peak its $\mathrm{CO}_{2}$ emissions before 2030. The latest analysis from the CAT indicates that $\mathrm{CO}_{2}$ emissions may, in fact, already have stopped increasing and reached peak levels" (http://www.climateactiontracker.org/ countries/china.html; last accessed 27 March 2018). Based on an extensive macro-economic analysis of China's industrial and broader economic structure, Green and Stern similarly conclude that "China's $\mathrm{CO}_{2}$ emissions from energy-if they grow at allare likely to grow much more slowly than under the old economic model and are likely to peak at some point in the decade before 2025" (Green/Stern, 2017: 435/36; for a more skeptical assessment see Peters, 2017). These may be strong indications of active efforts towards low-carbon patterns of growth in China, but what are the driving dynamics behind these changes, and what do they tell us about the future role of authoritarian China as climate change mitigation champion?

Any switch to low-carbon development rests on complex societal preconditions and requirements. This paper discusses the reasons for which the long-term effectiveness of China's authoritarian regime in lowering greenhouse gas emissions will be uncertain at best, because of internal contestation, low public and private-business participation, and countervailing strategies to secure China's global market positions. Understanding the foundations and the nature of China's possible leadership role in the move toward low-carbon emissions has important implications for the comparison of long-term decarbonization potentials between technocratic decision-making in authoritarian regimes and democratic decision-making in pluralistic systems. Finally, a better understanding is the foundation for decision-making on how to relate to China and how to foster low-carbon developments in all systems. The main section of this comment analyzes the drivers behind the switch toward low-carbon developments in China, showing that it is more a side-effect of other domestic concerns than the outcome of a coherent strategic policy switch. It also examines which factors influence the effectiveness of stateled non-participatory authoritarianism in China, and finally discusses selected future challenges derived from this analysis. In the final section, four practical implications are suggested.

\section{Drivers and inhibitors of China's shift to low-carbon development}

Chinese policy's approach to environmental problems has been analyzed as an example of environmental authoritarianism in the sense that it centralizes authority in a few executive agencies with the power to limit individual liberties and without the need to include non-state actors in the policy process (Gilley, 2012). 
Non-participation by both citizens and business actors seemingly allows the implementation of unpopular and costly measures in situations where such participation would prevent or slow changes in many liberal democracies. Gilley names a number of examples of the authoritarian character of the Chinese approach to environmental challenges, among them, typical commandand-control approaches such as excluding polluting enterprises from receiving state bank loans, directly shutting installations down, and enacting intentional power cuts to achieve energy reduction targets (Gilley, 2012; Balding, 2017). However, scholars have also emphasized that environmental policy in China has switched to a combination of many different approaches (Young et al., 2015), including the introduction of market-like instruments such as emissions trading (Engels/Wang et al., 2018). Even with a continued strong role of the central government, subject to the ideological guidance of the Communist Party, China's reality must be described as a multi-level system in which local and regional governments experience increasing levels of delegation (Schreurs, 2017). As a result, environmental improvements will more likely be the outcome of a coincidental alignment of interests than the outcome of an intentional top-down steering process.

The following paragraphs will show (1) which internal factors are driving China's switch to low-carbon development, (2) how specific features of China's state-led non-participatory authoritarianism will potentially weaken the effectiveness of this lowcarbon development, and (3) which long-term challenges stem from this analysis.

Drivers of China's switch to low-carbon development. Although China's low-carbon changes are widely recognized in the literature, most authors agree that they do not come as a direct outcome of responses to the climate challenge but rather as outcomes of three domestic challenges unrelated to global climate change (e.g., Green and Stern, 2017; Lo, 2015): addressing energy security, confronting the health and legitimacy crisis caused by poor air quality, and responding to weaknesses in the "old" economic growth model.

Energy security. The first driver, addressing energy security, originates from China's switch from a net energy exporter to a net energy importer. The abundance of domestic coal was not sufficient to satisfy the needs of the hyper-growth of industrial production in the 1990s, and the exploding numbers of motor vehicles increased the demand for oil. Increasing energy imports were a response to this scenario (Zhang et al., 2017). The growing dependence, especially on oil imports, became a concern for national policy leaders (Leung et al., 2014). A general reduction in energy demand was expected to decrease energy dependency and increase energy security.

Health and legitimacy crisis. The second driver, confronting the health crisis, is probably the one most visible to outside observers. The high number of coal-fired power plants, often with low efficiency and low environmental standards, can be seen as a strong driver of major air quality problems in vast urban conglomerations, especially in China's developed east. Addressing the air quality problem has become an issue of economic and political concern. The economic benefits of improved air quality are becoming more obvious (Sun et al., 2018), and perhaps even more importantly, the smog and haze crisis is increasingly leading to environmental mobilization (Deng and Peng, 2018). Confronting the health crisis and improving air quality by reducing the use of coal has, therefore, also become a question of political support for the Chinese government (Alkon and Wang, 2018).
Limits of the economic growth model. The third driver refers to responses to weaknesses in the old economic growth model, which was heavily export oriented, with a disadvantageous industrial structure and low innovation capacities and efficiency standards (Naughton, 2014). Acquiring technological leadership, e.g., in renewable energy technologies, is one way to overcome these limitations. In more general terms, switching to a more sustainable economic growth model has become a major concern of the Chinese government, and the concept of a low-carbon economy contains important elements of a model that is more promising to the party elite, as it also offers international symbolic recognition.

At least for these three domestic reasons, adopting a lowcarbon development strategy promises a number of win-winoutcomes, including energy security, improved health conditions, and industrial and technological modernization.

However, the question remains as to what China's global climate leadership role can be. Within the UN system, the climate issue offers China a field in which it is much easier to build up a positive reputation than in other fields such as human rights and labor rights. However, to better understand China's global leadership approach, it is more helpful to look outside of the $\mathrm{UN}$ system. One can observe that China is seeking global influence through heavy infrastructure investments abroad (Bräutigam, 2016). Two Chinese banks are the world leaders in global energy finance (Gallagher, 2018), but their investment portfolio is still based on fossil investments, such as coal-fired power plants. China's investment in neighboring Arctic countries shows that China wants to secure access to this region and to its natural (e.g., fossil) resources (Lasserre et al., 2017). Additionally, the "One Belt One Road" initiative represents major investments designed to secure access to export markets in the long run $(\mathrm{Yu}$, 2017). All of these initiatives might dilute or run counter to the global effect of domestic low-carbon developments.

To summarize, the drivers of China's low-carbon championship are rather indirect and can be viewed as a side-effect of other more pressing domestic demands. The concept of "environmental" authoritarianism is thus slightly misleading because it implies that an authoritarian approach is chosen in order to implement environmental goals, whereas it is more likely the outcome of a coincidental alignment of interests. The next section offers a closer look at the workings of this authoritarian approach and the question of effectiveness.

Factors that affect the effectiveness of China's state-led nonparticipatory authoritarianism. This section addresses the potential weaknesses of the Chinese authoritarian system due to internal contestation, fragmentation, and non-participation.

It is often assumed that an authoritarian regime allows consistent and unequivocal top-down implementation of goals and rules. However, as can be demonstrated in recent studies on programs in the fields of climate governance and energy transformation in China, many caveats apply to this naive assumption. First, even in authoritarian regimes we find competing goals and processes of internal contestation. Zhang et al. (2017) impressively describe this scenario with respect to changes in the Chinese energy strategy over time. With a proliferation of (more influential) actors, contestation has grown over control of Chinese national energy planning, e.g., over the relative importance of coal, nuclear, and renewables. Even if leaders of the Communist Party define the overall strategy, the regime cannot avoid the powerful constituencies that build up inside the system, with alignments possible between state agencies and state-owned companies, supported by universities and think tanks. Further down the implementation line, others describe typical constellations of conflict between energy companies and 
grid owners (Green and Stern, 2017), and between the central government and local governments, especially when local or provincial governments want to protect a development model heavily based on the production and consumption of coal against certain low-carbon ideas that are under development at the level of the central government (Lo, 2015). As a consequence, even in authoritarian regimes, goals cannot necessarily be implemented in a straightforward top-down manner. Even in China, at times leaders must wait until a window of opportunity opens up, as in the Myanmar-China energy pipeline (Liu et al., 2017a, 2017b). Along a similar line of reasoning, scholars have shown that the current dynamism of e-mobility innovation in China is occurring not because of central government activities, but "in spite of, in the interstices of and even because of the stasis, frustrations and disincentives of the official national plans for the electric car" (Tyfield and Zuev, 2018: p. 268).

The Chinese authoritarian approach to environmental crises has been described as distinctively non-participatory (Gilley, 2012). However, it becomes increasingly obvious that participation is not only occurring but is also crucial for effectively implementing any large-scale program on the ground. In a recent study on the emergence of the Chinese renewable energy strategy, Shen (2017) showed that this effort emerged as a new policy subsystem only because it was massively supported by emerging industrial interest groups that focus on renewable technologies. Business actors have gained influence in this new field, if only because government agencies are strongly dependent on information, e.g., on operational data from companies, market analyses, and trend forecasting (Shen, 2017: p. 91). Although this scenario is not participation in the more conventional understanding of public participation, the participation of business actors crucially contributes to the co-construction of prorenewable narratives. Such narratives help the renewable energy sub-system gain traction in the above-mentioned contestation with powerful and more traditional state actors in other energy fields, and contribute to the creation and reinforcement of shared beliefs.

Public participation and the willingness of local governments to implement policies and programs are crucial at other levels, too. Many case studies show and note that local renewable energy projects encounter difficulties in generating any long-term effect, let alone the intended effects, without the consultation and active participation of citizens or local groups (e.g., Geall et al., 2017). A recent comparative study on the deployment of solar water heating systems in two Chinese cities shows the importance of the coordinated action of multiple actors for such a program to have a long-term positive impact (Huang et al., 2018). The authors argue that the successful diffusion of a favorable low-carbon technology depends not only on physical and technological conditions but also on the complex socio-spatial embeddedness of the new technology. No less than reconstruction of everyday practices is needed, which is not possible without the active local participation of a wide range of multiple actors.

Therefore, one should think of the authoritarian regime in China as something of a fragmented power in a "labyrinthine and complicated governance structure" (Zhang et al., 2017: p. 641) in which responsibilities for energy pricing, various energy projects, authority over state-owned energy companies and adjustment of electricity rates are spread across many different ministries and agencies. This scenario will clearly affect the effectiveness of China in becoming a world champion and leader in low-carbon development in the long run. Even in authoritarian regimes, successful long-term implementation of a coherent low-carbon strategy goes through a process of contestation, and central actors must build alliances with other supporting actors and encourage the active participation of local authorities and the public as an important "recipient" and future "bearer" of low-carbon practices.

Long-term challenges stemming from this analysis. Low-carbon development must include more far-ranging changes than have so far been achieved in any country if the meaning of the CoP 21 Paris Agreement is to be taken seriously, i.e., complete decarbonization in the course of this century. Technocratic authoritarian governments can have an advantage in making centralized policy decisions over strategic switches, e.g., in redirecting a country's energy system towards low-carbon goals by gradually replacing fossil fuels with renewable energy sources. However, even with these strategic moves, the implementation of these goals and strategies requires much coordination, the building of alliances, and even meaningful participation at all policy levels, and this is especially the case for China with its complex, multilevel policy system (Schreurs, 2017). It is likely that the controversy over energy and low-carbon goals and the ways in which to implement them will remain strong over a long period of time in China, as in any other political regime that is attempting to achieve this type of departure from its previous path. For the future development of the Chinese energy strategy, some authors expect rather more fragmentation, inconsistency, tension, and countervailing trends than less (e.g., Zhang et al., 2017).

The fact that low-carbon development is in conflict with other important goals is true in any political context. In China, the lowcarbon goal will always compete with the one overriding concern that has been driving the regime for decades: political stability (Lo, 2015). Because the low-carbon achievements thus far have primarily been the side effects of domestic strategic goals, the future of China's role as a low-carbon champion, therefore, depends on stable long-term win-win-constellations. Due to the factors discussed in the preceding section-internal contestation, fragmentation, limited participation, and limited transparencythe Chinese approach to low-carbon development will most likely be volatile rather than stable.

Moreover, the more the process of decarbonization advances, the more it will be dependent on local engagement as well as broad and active participation. This observation has been discussed extensively as it relates to the role of cities, which have great potential in China to contribute to climate mitigation because of their sheer size and number, and also as it relates to the enormous difficulty of achieving any positive trends (Wang et al., 2018). Additionally, civil engagement represented by nongovernmental organization (NGOs) is fairly insignificant. Young et al. (2015) count several hundred NGOs in the field of environment, but only a few are working on climate change, and they have a rather weak role in Chinese climate governance so far (Liu et al., 2017a, 2017b). Ironically, the US example recently showed that sub-national and local levels can act decisively in low-carbon development trends, even in the absence of a supportive strategy at the level of the federal government (http://climateactiontracker.org/countries/usa.html; last accessed 02 April 2018).

Other challenges refer to uneven law-enforcement (Wang, 2017; Eaton and Kostka, 2017), and to a number of transparency and accuracy problems in particular in carbon and energy data (Guan et al., 2012; Korsbakken et al., 2016). These combined challenges will create the grounds for weak results if China attempts to achieve deep decarbonization. Deep decarbonization will require any country to win the support of its population, not only to achieve passive acceptance but also to gain their support as actors in adopting new daily practices. This effort is difficult in pluralistic democratic systems, as is well understood. However, even China's authoritarian system will not escape these challenges 
in the long run. Although the Chinese population is increasingly silenced even in matters of the environment (which was once considered less political and, therefore, less sensitive, thus allowing for more liberal action) and the change in leadership every 10 years has been eliminated, it will be important to strengthen the opportunities for local engagement.

\section{Implications and possible actions}

This section concludes by describing the implications, which this comment evokes, on how to focus research on low-carbon transformations, including a reassessment of civil engagement and public participation, what to expect of China's role as climate champion in the future, and how to incorporate China's infrastructure investments into the climate picture.

Firstly, the critical discussion of popular assumptions about the effectiveness of environmental authoritarianism shows that a deeper analysis is needed of the broader societal preconditions and requirements of low-carbon transformations. Instead of just assuming top-down-implementation capacities, one should dissect the actual power relations including processes of internal contestation and fragmented authority. Careful analysis of the workings of climate governance helps to reveal what works and how and in which contexts. Research on low-carbon transformation should not only include additional macro-economic analysis, as Green and Stern (2017) suggest, but also the broader social dynamics, because they are the grounds on which sweeping changes of a seemingly technological nature can flourish.

Secondly, this includes a more careful assessment of the critical role of civil engagement and public participation. Because deep decarbonization over time must take place at local (e.g., city) levels and involves wide-ranging structural changes, the adoption of new daily practices, mobility patterns etc., there is no method of achieving this goal without massive support by the public. Research on successful transformations emphasizes that public participation, although conflicting and time-consuming at times, is more of a valuable resource for transformation than a barrier. This also needs to be taken into account more systematically in assessments of recent energy transitions in democratic countries, where this is sometimes only reluctantly acknowledged in spite of pluralistic and participatory cultural traditions, as recent studies point out (e.g., Galvin, 2018).

The arguments brought forward in this comment raise the question why one would expect China to step in as the new global climate leader. China might turn out to be an (inadvertent) disruptive innovator in low-carbon transitions (Tyfield, 2018), or it might continue its shift towards low-carbon development if and to the extent that this continues to coincide with more important priorities. However, based on the analysis put forward in this comment, one should not expect China to provide strong intentional leadership when it comes to consistently strengthening the global climate mitigation regime. Nonetheless, it might be a good response to engage in collaboration with China at all relevant levels, through all available channels, as with all other large emitters that will eventually become game changers through sheer size. For the very reason that it is far from obvious that the favorable stance of China's political elite towards low-carbon development will stand the test of time, multiplying solid win-win constellations is of paramount importance.

Finally attempts to understand China's effectiveness in coherent low-carbon development should include more than climate governance and the transformation of the energy system. It is important to get the broader picture of what actually influences qualitative shifts towards low-carbon development. An attempt to get the broader picture redirects one's attention towards China's current geo-political expansion and the competition for global market positions. If one of China's main drivers in reducing the use of coal is domestic air quality (and the related health problems), this does not automatically exclude exporting fossil-based economies to other parts of the world. The current drive toward globalization of China's influence through gigantic infrastructure investment projects outside of China must be considered as well. China's role in global energy finance, its investments in Arctic countries and the "One Belt One Road" initiative might be more influential for global low-carbon transformations than any policy officially identified as fostering climate mitigation.

Received: 4 April 2018 Accepted: 28 June 2018

Published online: 14 August 2018

\section{References}

Alkon M, Wang EH (2018) Pollution lowers support for china's regime: quasiexperimental evidence from Beijing. J Polit 80(1):327-331

Aykut SC (2016) Taking a wider view on climate governance: Moving beyond the 'Iceberg', the 'Elephant', and the 'Forest.'. WIREs Clim Change 7:318-328

Balding C (2017) Why China's freezing. A well-meaning anti-pollution push turned into a debacle. In: Bloomberg View, 12.12.2017. Available at: https:// www.bloomberg.com/view/articles/2017-12-11/why-china-s-freezing [accessed 27 March 2018]

Biesecker M, Watt L (2017) Trump boosts coal as China takes the lead on climate change. The Associated Press/Business Insider, 6 April, 2017. Available at: https://www.businessinsider.com/ap-trump-boosts-coal-as-china-takes-thelead-on-climate-change-2017-4?IR=T [accessed ab 6 August, 2018]

Bräutigam D (2016) The dragon's gift: the real story of China in Africa. Oxford University Press, Oxford

Deng X, Peng S (2018) Trust, norms and networks in social media environmental mobilization: a social capital analysis of Under the Dome in China. Asian J Commun 0(0):1-15

Eaton S, Kostka G (2017) Central protectionism in China: The "Central SOE Problem" in environmental governance China Q 231:685-704

Gallagher KP (2018) China's global energy finance: poised to lead. Energy Res Social Sci 35:15-16

Galvin R (2018) 'Them and us': Regional-national power-plays in the German energy transformation: A case study in Lower Franconia. Energy Policy 113:269-277

Geall S, Shen W, Gongbuzeren (2017) Solar PV and Poverty Alleviation in China: Rhetoric and Reality, STEPS Working Paper 93, STEPS Centre: Brighton

Gilley B (2012) Authoritarian environmentalism and China's response to climate change. Environ Polit 21(2):287-307

Green F, Stern N (2017) China's changing economy: implications for its carbon dioxide emissions. Clim Policy 17(4):423-442

Guan D, Liu Z, Geng Y, Lindner S, Hubacek K (2012) The Gigatonne gap in China's carbon dioxide inventories. Nat Clim Change 2:672-675

Huang P, Broto VC, Liu Y, Ma H (2018) The governance of urban energy transitions: A comparative study of solar water heating systems in two Chinese cities. J Clean Prod 180:222-231

Korsbakken JI, Glen PP, Robbie MA (2016) Uncertainties around reductions in China's coal use and $\mathrm{CO}_{2}$ emissions. Nat Clim Change 28:1-5

Kuyper JW, Linnér B-O, Schroeder H (2018) Non-state actors in hybrid global climate governance: justice, legitimacy, and effectiveness in a post-Paris era WIREs Clim Change 9:e497

Lasserre F, Huang L, Alexeeva O (2017) China's strategy in the Arctic: Threatening or opportunistic? Polar Rec 53(1):31-42

Le Quéré C et al. (2018) Global Carbon Budget 2017. Earth Syst Sci Data 10 (1):405-448

Leung GCK, Cherp A, Jewell J, Wei J-M (2014) Securitization of energy supply chains in China. Appl Energy 123:316-326

Li J, Wang X (2012) Energy and climate policy in China's twelfth five-year plan: A paradigm shift. Energy Policy 41:519-528

Liu D, Yamaguchi K, Yoshikawa H (2017a) Understanding the motivations behind the Myanmar-China energy pipeline: Multiple streams and energy politics in China. Energy Policy 107:403-412

Liu L, Wang P, Wu T (2017b) The role of nongovernmental organizations in China's climate change governance. Wiley Interdiscip Rev: Clim Change 8(6): e483

Lo K (2015) How authoritarian is the environmental governance of China? Environ Sci Policy 54:152-159

Naughton B (2014) China's Economy: Complacency, crisis \& the challenge of reform. Dædalus, J Am Acad Arts Sci 143(2):14-25 
People's Republic of China (2015) China's first NDC submission. http://www4. unfccc.int/ndcregistry/PublishedDocuments/China\%20First/China\%27s\% 20First\%20NDC\%20Submission.pdf [accessed 02 April 2018].

Peters G 2017 Have Chinese emissions peaked? Klima - Et magasin om klimaforskning fra CICERO. 30.03.2017 [accessed 06 June 2018]

Schreurs M (2017) Multi-level climate governance in China. Environ Policy Gov 27 (2):163-174

Shen W (2017) Who drives China's renewable energy policies? Understanding the role of industrial corporations. Environ Dev 21:87-97

Sun D, Fang J, Sun J (2018) Health-related benefits of air quality improvement from coal control in China: Evidence from the Jing-Jin-Ji region. Resour, Conserv Recycl 129:416-423

Tyfield D (2018) Innovating innovation-Disruptive innovation in China and the low-carbon transition of capitalism. Energy Res Social Sci 37:266-274

Tyfield D, Zuev D (2018) Stasis, dynamism and emergence of the e-mobility system in China: A power relational perspective. Technol Forecast Social Change 126:259-270

Urban F (2018) China's rise: Challenging the North-South technology transfer paradigm for climate change mitigation and low carbon energy. Energy Policy 113:320-330

Wang B (2010) Can CDM bring technology transfer to China?-An Empirical Study of Technology Transfer in China's CDM projects. Energy Policy 38 (5):2572-2585

Wang J (2017) Evolution of environmental thought and enforcement of environmental protection legislation in China: The Status Quo. In: Kitagawa H (ed) Environmental policy and governance in China. Springer, Tokyo, pp. 17-46

Wang C, Engels A, Wang Z (2018) Overview of research on China's transition to low-carbon development: the role of cities, technologies, industries and the energy system. Renew Sustain Energy Rev 81(1):1350-1364

Young $\mathrm{O}$ et al. (2015) Institutionalized governance processes comparing environmental problem solving in China and the United States. Glob Environ Change 31:163-173

Yu H (2017) Motivation behind China's 'One Belt, One Road' Initiatives and establishment of the Asian infrastructure investment bank. J Contemp China 26(105):353-368
Zhang L, Sovacool BK, Ren J, Ely A (2017) The Dragon awakens: Innovation, competition, and transition in the energy strategy of the People's Republic of China, 1949-2017. Energy Policy 108:634-644

Zhao H (2017) China steadfast on climate support. China Daily USA 3 March 2017. http://usa.chinadaily.com.cn/epaper/2017-03/30/content_28737030. htm. [accessed 28 March 2017]

\section{Additional information}

Competing interests: The author declares that she has no competing interests.

Reprints and permission information is available online at http://www.nature.com/ reprints

Publisher's note: Springer Nature remains neutral with regard to jurisdictional claims in published maps and institutional affiliations.

(c) (i) Open Access This article is licensed under a Creative Commons Attribution 4.0 International License, which permits use, sharing, adaptation, distribution and reproduction in any medium or format, as long as you give appropriate credit to the original author(s) and the source, provide a link to the Creative Commons license, and indicate if changes were made. The images or other third party material in this article are included in the article's Creative Commons license, unless indicated otherwise in a credit line to the material. If material is not included in the article's Creative Commons license and your intended use is not permitted by statutory regulation or exceeds the permitted use, you will need to obtain permission directly from the copyright holder. To view a copy of this license, visit http://creativecommons.org/ licenses/by/4.0/.

(C) The Author(s) 2018 